Review

\title{
Educational Tourism and Local Development: The Role of Universities
}

\author{
Sabrina Tomasi *(D), Gigliola Paviotti $\mathbb{D}$ and Alessio Cavicchi ${ }^{\mathbb{D}}$ \\ Department of Education, Cultural Heritage and Tourism, University of Macerata, 62100 Macerata, Italy; \\ gigliola.paviotti@unimc.it (G.P.); a.cavicchi@unimc.it (A.C.) \\ * Correspondence: s.tomasi@unimc.it
}

Received: 18 June 2020; Accepted: 17 August 2020; Published: 20 August 2020

\begin{abstract}
On the basis of a scoping review of the literature about educational tourism-a type of tourism in which the traveller's primary or secondary objective is learning-this study summarizes views on how Higher Education Institutions (HEIs) can foster local development through educational tourism. The results show that international students can be considered as educational tourists, and their stay can benefit them and the destination. In this context, the university can actively facilitate relationships between tourists and local stakeholders to foster learning at the destination and improve the sustainability of the local economy; some reports about specific cases are described. We argue that the tourism component should be considered by any institution organising or managing educational programmes, in order to exploit the opportunities offered by the destination for the achievement of learning goals. More specifically, the paper focuses on educational tourism related to HEI students in international mobility programs, who are educational tourists inasmuch as their overall experience at the destination includes leisure and tourism activities. Further research is needed to formulate models of intervention.
\end{abstract}

Keywords: educational tourism; local development; higher education

\section{Introduction}

In the last few decades, the number of students studying abroad has increased throughout the world, with important outcomes for the host universities and countries, as well as the students themselves. According to UNESCO, an internationally mobile student is an individual "who has physically crossed an international border between two countries to participate in educational activities in a destination country, where the destination country is different from his or her country of origin" (UNESCO Glossary: http://uis.unesco.org/en/glossary-term/international-or-internationally-mobile-students). The advantages of study-abroad programs accrue to the host country as well as to the student. On the one hand, host countries benefit from international student expenditures on accommodation, food and beverages, entertainment and leisure activities, and, in some programs, tuition fees, not to mention the inevitable taxes, with a positive impact on the economy [1]. On the other hand, students benefit not only from their studies, but also from interactions with local and foreign people, and experiences that foster personal and professional growth. Additionally, international students are tourists, taking advantage of the opportunities to visit local attractions or travel to other regions of the host countries, alone or with friends and relatives. Experiential learning is part of studying abroad, and tourism is part of the whole experience [2]. It is a transformative [3,4] combination of learning and personal growth [5], thus creating a complete social experience [6,7]. The most frequently cited reasons for choosing a particular university abroad are the quality of education offered and the attractiveness of the destination [8-14]. In a parallel development to the growth in the number of students who study abroad, universities in recent decades have become progressively more committed to their third mission-to boost the local economy 
through the promotion of technology transfer to businesses [15]. Moreover, through their engagement in place-based, multi-stakeholder partnerships, they have sought to bring innovation to bear in addressing local and world challenges [16]. In this environment, universities also pursue their civic mission $[17,18]$ in a holistic way [18], by involving students in educational activities with the local community, thus providing opportunities to practice active citizenship, gain knowledge, and improve their employability. In this context, universities and their local areas also benefit when talented international students chose to stay and work in the host country, putting to use the skills they have learned there; this can support the process of innovation and the development of production systems, providing skilled workers for the future of the local area [1]. In addition, international student mobility may promote future international scientific co-operation networks and cross-faculty fertilisation [19], thus creating benefits for the host university, the destination and the students themselves.

\subsection{Purpose and Organization of the Study}

This study investigates the role of universities in fostering local development through educational tourism. First, we provide a brief description of the methods used for the literature survey and the definitions of educational tourism put forth in the literature. Second, we define the role of travel as part of the educational experience. Third, we explore the role of universities as place-based education providers in a region. We then examine the role of universities in improving the potential for the provision of educational tourism in their areas and thus fostering local development. Fourth, the impact of educational tourism is presented, drawing upon examples in the literature.

\subsection{Background Context}

To better understand the dynamics of study abroad in recent years, some statistics and data are helpful. According to the UNESCO Institute for Statistics, there were over 4.8 million international students in 2016, up from 3.9 million in 2011, as reported in the Global Migration Indicators [20]. More than $50 \%$ of these students were enrolled in educational programmes in six host countries; namely, the United States of America, the United Kingdom, Australia, France, Germany and the Russian Federation. Prominent sending countries of international students included China, India, Germany, South Korea, Nigeria, France, Saudi Arabia and several Central Asian countries. In 2013-2014, American students abroad numbered 304,465, with Europe as their favourite destination, in particular the U.K., Italy, Spain, France, and Germany. China, Ireland, Australia, Japan and South Africa also hosted significant numbers of American students. Looking at data for the OECD area, in 2016, there were 3.5 million international or foreign students [21], over half of them from Asia, especially China (1.9 million, 55\% of all international students in 2016), and they chose the U.S., U.K. and Australia as destinations. Europe is the second major region of origin, with 845,000 European cross-border students. $80 \%$ of these European students travel to other European nations for study, perhaps because of the Erasmus mobility program between universities, which, in its 30 years of activity, has enabled study abroad for 4.4 million European students and university staff [22]. In 2014, the Erasmus+ program was launched to expand beyond Europe's borders and to offer an opportunity to study, train or volunteer abroad not only to university students but also to vocational students, apprentices, teachers, youth workers and volunteers; as of 2017, up to 2 million Europeans had participated in its mobility programmes.

Moving from the discussion of student origins to that of their destinations, the U.S. was the top OECD destination country for mobile tertiary students (971,000 students) in 2016. The European Union (1.6 million students) was another key destination [21,23]. The U.K. was the destination of choice for $26 \%$ of the total number of students from abroad. In fact, in 2014-2015 there were approximately 437,000 international students enrolled, $19 \%$ of all students registered at U.K. universities. Of these, 125,000 came from other EU member states and 312,000 from the rest of the world [24]. France and Germany (both at 245,000 ) were also major host countries, followed by Italy $(93,000)$, the Netherlands $(90,000)$ and Austria $(70,000)$. Of international students, $26 \%$ are Europeans, $29.5 \%$ come from Asia, 
and $12.7 \%$ are from Africa; in 2016, they came to the European Union for bachelor's degrees (46\%), master's degrees $(41 \%)$, doctoral degrees $(10 \%)$, and short-cycle tertiary courses $(3 \%)$, according to EU learning mobility statistics [23].

The economic impact for host countries has been considerable, as detailed in studies for the U.S., Italy and the U.K [24-26]. In the U.S., during the academic year 2017-2018, the 1,094,792 international students contributed $\$ 39$ billion to the economy and supported more than 455,000 jobs [25]. A 2013 study by the Association of American College and University Programs in Italy stated that the value added created by these international educational programs was particularly significant in the education sector $(46.9 \%$ of the total impact in terms of value added generated by the presence of international students), because of tuition expenditures. Economic impact in other sectors was not negligible either: real estate $(1.2 \%)$, sales $(6.9 \%)$, food and beverage (5.8), transport $(40 \%)$, and other services, among them arts and entertainment (more than $1 \%$ ), were affected. The tertiary sector was most impacted, which creates opportunities for the development of more services and benefits, above all in those destinations where the programs are well developed [26]. Detailed information on the economic impact of international students in the U.K. during the academic year 2014-2015 [24] is provided in Table 1.

Table 1. Economic impact of international students in the U.K. (a. y. 2014-2015) [24].

\begin{tabular}{|c|c|c|c|c|c|}
\hline \multicolumn{6}{|c|}{ Economic Impact of International Students in the U.K. (a. y. 2014-2015) } \\
\hline \multicolumn{5}{|c|}{ Type of Economic Contribution } & \multirow{2}{*}{$\begin{array}{c}\text { Overall } \\
\text { Contribution } \\
\text { to U.K. } \\
\text { Economy }\end{array}$} \\
\hline $\begin{array}{c}\text { Payment of } \\
\text { Tuition Fees to } \\
\text { U.K. Universities }\end{array}$ & $\begin{array}{c}\text { Payment of } \\
\text { Tuition Fees }+ \\
\text { Accommodation }\end{array}$ & $\begin{array}{c}\text { Off-Campus } \\
\text { Expenditure + } \\
\text { Visitors' } \\
\text { Expenditure }\end{array}$ & $\begin{array}{c}\text { Transport and } \\
\text { Retail Sectors (\% of } \\
\text { the Total Increase in } \\
\text { Economic Output) }\end{array}$ & $\begin{array}{c}\text { Tax Revenues } \\
\text { for the U.K. } \\
\text { Exchequer }\end{array}$ & \\
\hline$£ 4.8$ billion & $\begin{array}{l}\text { - Additional } \\
£ 13.5 \text { billion in } \\
\text { gross output; } \\
\text { - } £ 13.8 \text { billion: } \\
\text { contribution to } \\
\text { gross value } \\
\text { added to GDP }\end{array}$ & $\begin{array}{l}\text { - } £ 25.8 \text { billion in } \\
\text { gross output in } \\
\text { the UK; } \\
\text { - } £ 13.8 \text { billion: } \\
\text { contribution to } \\
\text { gross value to } \\
\text { GDP }\end{array}$ & $13 \%$ and $12 \%$ & $£ 1$ billion & $£ 6.1$ billion \\
\hline
\end{tabular}

Among the factors related to educational tourism that economically contribute to the host destination, it is worth mentioning the expenditures of friends and relatives who visit the international students. In the U.K. in 2014-2015, visitors spent about $£ 520$ million for transport, hotels, hospitality, and cultural, recreational and sports attractions, generating an estimated $£ 1$ billion in gross output. Their presence supported a further 11,000 jobs and $£ 100$ million in tax revenues [24].

Moving on to the discussion of the benefits that accrue to the students themselves, two studies contribute useful insights. A 2002 publication on a longitudinal study of alumni of study abroad programs run by the Institute of International Education of Students [27] reported that $98 \%$ of respondents believed study abroad helped them to understand their own cultural values and biases better, and $82 \%$ felt that the experience gave them a more sophisticated way of looking at the world. For $94 \%$ of the alumni, the study-abroad experience continued to influence their interactions with people from different cultures. The choice of subsequent educational experiences was influenced by the study abroad experience for $87 \%$ of respondents; nearly half of all respondents went on to international work or internships (usually in offices) and/or international volunteerism. The second study, the Erasmus Impact Study [28], reported that most respondents felt that their future career paths were influenced by the skills acquired during their study abroad period. The study also reported that companies are willing to hire students who studied at foreign universities, because they feel that this kind of experience would have helped them acquire transversal skills important for the world of work. 


\section{Materials and Methods}

Our research question for this literature review was "What is the role of HEIs in fostering local development through educational tourism?" The first phase of desk research focused on collecting academic contributions about educational tourism using the Google Scholar search engine, Scopus, EBSCO and the Web of Science databases, and the Academia.edu and Research Gate academic social networks, for the following keywords: "educational tourism"; "educational tourism"; "educational travel"; "study abroad"; "learning experience"; "learning destination"; "experiential learning"; "learning backpackers"; "international students" combined with "tourism"; "rural tourism" combined with "education"; "civic university". The authors perused the abstracts and chose those most suited to the purpose of this study for in-depth reading. Both conceptual papers and case studies, the latter applying both qualitative and quantitative methods, were considered. From a first selection of over two hundred papers, about one hundred were chosen and categorized into clusters according to these main topics:

1. Educational tourism (in general): definitions and frameworks related to educational tourism.

2. Travel and experiential learning: connections between educational tourism, travel and experiential learning.

3. Educational tourism destinations. How can the stakeholders in a destination manage local educational tourism to contribute to local development, and how can universities, significant stakeholders in their own right, contribute to the touristic offer? This topic also includes the concept of civic university.

4. The educational tourism of international students. What are the characteristics of international students as educational tourists? What motivates a student to choose international mobility, and what criteria determine the choice of a destination?

5. The social benefits of educational tourism for international students and the destination. What personal benefits do international students gain from educational tourism? How does the presence of international students impact a destination?

6. The impact of educational tourism. What is the impact of educational tourism on a destination?

Next, the content in each cluster deemed most pertinent to the current or potential role of universities for local development through educational tourism was identified, analysed and synthesized for the third section, 'Results and Discussion', organized as:

- Section 3.1. Defining educational tourism: cluster 1;

- Section 3.2. Educational tourism and travel: cluster 2;

- Section 3.3. The role of higher education institutions in fostering educational tourism: clusters 3,4 and 5;

- Section 3.4. Impact of educational tourism on the destination: cluster 6;

\section{Results and Discussion}

\subsection{Defining Educational Tourism}

The aspect of educational tourism has been studied as part of tourism research since the 1990s [29-32]. Several definitions of educational tourism can be found in the literature, as summarized in Table 2.

Educational tourism as a concept, therefore, refers to common topics, such as formal education, travel, tourism and skills, but precise attributes have yet to be agreed upon. The ongoing debate concerns the motivation of the learner/traveler, the links between formal and informal learning, and the relation between tourism and education. 
Table 2. Definitions of educational tourism in the literature.

\begin{tabular}{|c|c|}
\hline Definition of Educational Tourism & Authors \\
\hline $\begin{array}{l}\text { "Educational tourists (students, adults, and seniors) are those respondents } \\
\text { who indicated that they took part in study tours or who attended } \\
\text { workshops to learn new skills or improve existing ones while on vacation" }\end{array}$ & Gibson [33] \\
\hline $\begin{array}{l}\text { "Tourist activity undertaken by those who are undertaking an overnight } \\
\text { vacation and those who are undertaking an excursion for whom education } \\
\text { and learning is a primary (education first segment) or secondary (tourism } \\
\text { first segment) part of their trip" (p. 18). }\end{array}$ & Ritchie [32] \\
\hline $\begin{array}{l}\text { "A form of tourist experience that explicitly aims to provide structured } \\
\text { learning in situ through active and engaged intellectual praxis. Learning is } \\
\text { explicit and core to the delivery of the product" (p. 6). }\end{array}$ & Pitman et al. [34] \\
\hline $\begin{array}{l}\text { "Organised trip led by skilled guides where leisure-travel activities and } \\
\text { learning processes occur simultaneously through interaction between } \\
\text { related stakeholders (participants, tour operators/leaders, and local } \\
\text { community) as part of the total experience. The educational tourism } \\
\text { experience occurs within a certain period of time (minimum of } 24 \text { h away } \\
\text { from home) and generally ensues in an informal setting." (p. 107) }\end{array}$ & Sie et al. [7] \\
\hline
\end{tabular}

Falk et al. [35] did not offer a precise definition of educational tourism, but explored the nexus between travel and learning, arguing that there is always a learning component in travel, even if it is often a passive one. They noted that the development of practical skills and the acquisition of knowledge occur in spontaneous and incidental ways. Practical wisdom, understood as learning and awareness about sustainable and ethical behaviour and cultural views can be achieved, as exposure to diverse contexts contributes to a cumulative process of experiencing. Conversely, they acknowledge that some travel-for example sailing or golfing trips—is undertaken with the specific, intentional goal of learning, an "active quest for controlling physical and cognitive skills and acquiring understanding and knowledge" (p. 917). This point seems to echo the education/tourism first dichotomy of Ritchie [32], as in Table 1. McGladdery and Lubbe [4] also referred to Ritchie in their description of educational tourism as a transformative process that joins elements of experiential learning and international education, and provides several measurable outcomes, categorized as cognitive (knowledge acquired), affective (attitudes, or ways of thinking), and behavioural (skill development). McGladdery and Lubbe also discussed motivation, arguing that it is not always easy to determine whether the desire to learn while travelling is a primary or secondary motivation. Moreover, they explored a factor not considered by Ritchie, asking whether educational tourism includes ecotourism or cultural tourism. Even if it is acknowledged that learning occurs anyway during travels, authors do not all agree on the need of having an education institution driving the learning process. Sie et al. [7] defined educational tourism as an organised leisure-travel trip which lasts at least $24 \mathrm{~h}$ and usually takes place in an informal setting. Educational tourism is related to non-formal learning and is a form of self-directed learning while travelling; education and tourism are the core services. It encompasses study tours for adults (active discovery or special interest) and study tours during school holidays. They do not consider university study projects in this category, viewing them instead as "formal learning", in which education and learning are the core services. Instead, Pitman et al. [34], whose definition, as in Table 2, noted three characteristics of educational tourism for adults [36]: (a) an intentional pedagogical structure; (b) an educational leader/teacher; and (c) in situ experience that triggers an emotional, sensory reaction in the learner, which in turn facilitates transformative learning. According to them and other authors, personal and pleasurable pursuit in which the learning moment is structured and facilitated by an expert and supported by materials has the potential to transform the learner, and therefore has the potential to be transformative learning [3,32,36].

In 2016, Nugroho and Soeprihanto [37] explored the relationship between the fields of education and tourism in more depth. They described educational tourism as a three-dimensional product: 
(a) the educational experience at the tourism destination and the consequent learning benefit (main product); (b) the tourist package, which meets the tourist's needs (real product); (c) all the tangible and intangible aspects of the tourism experience, which are added to the primary service (additional product). Furthermore, they identified different formats of educational tourism: school trips (and perhaps a follow-up visit with the children's parents); study abroad experiences (intensive study sessions with full cultural and linguistic immersion); seminar vacations/senior seminars/hands-on enhanced experience vacations (which mostly appeal to adults and seniors); skills enhancement vacations (trips with several practical learning activities, such as 'how-to-do' learning or ecology-based activities); and educational cruises (which combine fun and specific-topic lectures).

In this paper, we consider educational tourism as a learning experience organised and managed by educational institutions. Of course, learning takes place during any kind of travel, for leisure or to visit a destination, for example, but in our definition, education is the learner's primary purpose and tourism the secondary one. However, we argue that the tourism component should be considered by any institution organising or managing educational programmes, in order to exploit the opportunities offered by a destination for achieving learning goals. More specifically, the paper focuses on educational tourism related to HEI students in international mobility programs, who are educational tourists inasmuch as their overall experience at the destination includes leisure and tourism activities [2].

\subsection{Educational Tourism and Travel}

Travel is a fundamental aspect in any definition of educational tourism, as it plays a significant part in the entire experience: travel satisfies the desire to learn about the culture and the customs of a place [24,38]. While travelling, tourists are actively involved in their "cognitive, emotional and bodily dimensions [39]", and learning becomes possible through the direct experience, which is "meaningful discovery" [40]. Liang et al. [41] focused on the motivation for travel and on the value of leaving one's comfort zone, and of reflection during and after the journey, and proposed the development of an individual travel biography to facilitate learning. Richards [3] argued that educational tourism, including ecotourism, cultural tourism and agri-tourism, can be transformative and related to experience, referring to the experience value of Pine and Gilmore [5], where education also entails learning and personal growth.

Experiential learning $[40,42,43]$ is an essential part of the experience of tourism, and consequently is particularly significant when it comes to educational tourism, where the learning component is core. Experiential learning in the tourism context has been studied by several scholars $[32,34,44]$. Travel necessarily involves experiential learning. Pine and Gilmore [5] define four experience realms-education, aesthetics, entertainment and escape-that can be considered part of the four dimensions of active vs. passive, and absorption vs. immersion. Education provides active and absorbing experiences. In a survey of tourists and providers regarding adult educational tourism, Pitman et al. [36] found that customers linked the travel experience to learning about a country through its history, art, food and culture. Intentional learning to open one's mind and reinforce knowledge, context-related experiential involvement, and the combination of travel and a structured educational programme are three key elements in educational tourism [36]. The learning experience in educational tourism involves providers, practitioners and learners, and it goes beyond the actual touristic experience. It includes pre-travel considerations (product development, personnel recruitment and learner preparation) and after-travel moments related to the learning communities and the maintenance of learner social links. Furthermore, spending some time during the experience to absorb and share it with the other actors enhances reflection and thus learning [36].

\subsection{The Role of Higher Education Institutions in Fostering Educational Tourism}

In recent decades, universities have paid increasing attention to their engagement with civic society, collaborating in place-based projects with local stakeholders to enhance sustainable local economic development [45]. In this process, specific needs are identified, and then innovative solutions 
to real problems are proposed $[16,46,47]$ in efforts that draw upon and share the specialized knowledge of academics and the particular knowledge of locals, especially their culture, with its traditions and values [17], to foster sustainable development and bring other benefits to the local area [48].

\subsubsection{Universities and Educational Tourism}

Pitman et al. [34] studied the role of higher education institutions in educational tourism, recognizing that "educational tours are an interesting site of study, first, because they are explicitly about learning, and second, because they provide an opportunity for universities to reach beyond their walls and directly teach members of the broader community" (p. 6). They argued that universities could play a pivotal role in teaching ethics beyond the context of academic education by providing moral education that supplements professional skills, and by using the entire world as a stage for pedagogy, and asserted that, by applying mixed strategies, such as practical and experiential learning at a local level, and by exposing students to real life, it is possible to increase the links between the university and the community. Liang et al. [41] also highlighted the role of higher education teachers in the learning process: "Educators, who have the opportunity to get to know individual students more closely and to work with them repeatedly in thinking about travel and learning in advance of a trip, in digesting the trip as it is happening, and in reflecting on it after they return, are in an even stronger position to facilitate students' growth through travel and to direct their awareness towards ways their learning may be turned in the service of social transformation" (p. 236).

By engaging in educational tourism, universities also pursue their civic mission for the benefit of the local area. A civic university integrates teaching, research and engagement with the outside world, according to Goddard et al. [18]. From the results of dialogue with local stakeholders, HEIs can form students into "well-rounded citizens" (p. 13) capable of providing answers to the real challenges of the territory in terms of innovation [17]. A civic university has a sense of purpose and place, viewing the territory as a "living laboratory" where it has cultural and social impact. For this reason, it actively engages and collaborates with public and private local stakeholders, and with other educational and research institutions and departments at a local and international level. It takes a holistic approach and shows a willingness to invest to achieve societal goals, and operates with transparency and accountability, and by applying innovative methodologies to be more effective. HEIs play a pivotal role in innovation for society and sustainable development, as they are a means of cross-fertilisation and co-creation in different thematic areas and for different actors, by contributing to the generation of knowledge that is trans-disciplinary and practice-based [49].

In the context of hosting educational tourism, universities can also achieve their civic purposes [17]. For example, they could run place-based research and extend teaching to address the challenges faced by local society, also with the aim to valorise the place. The holistic approach and sense of place could lead them to create new connections with other universities and local stakeholders, involving students in local activities. This could be done through specific projects and by using new methodologies and approaches. An intriguing example is a proposal to organise educational tourism at GadjahMada University in Indonesia, given the interesting architecture on campus, the Biology museum, and the natural beauty of the surrounding areas [37]. The authors argue that to pursue these objectives, university and tourism stakeholders need to create tourism programs and learning materials, and the government should be involved in policy planning, the identification of resources and the management of infrastructures. The community should also play an active role in planning and should inform the other actors about the local culture, engage local residents in social commitment, and develop the human resources of its members, so that educational tourism can continue in the area. Thus, universities could satisfy both the government's and the tertiary sector's needs, and address policy and market challenges [34]. Furthermore, local activities foster the engagement of the young and adult learners of the local community, alongside university students, thus creating a multi-stakeholder learning community that could also address societal and ethical issues. To be sustainable, the development of 
educational tourism practices in a destination, where the university always plays a coordinating role, should be the result of the combination of the $3 \mathrm{E}$ principles [50]:

- Environmental factors: provide tourists with knowledge-based information and educate them to respect the local environment. Sustainable actions promote the preservation of biodiversity and enhance attention to the cultural heritage;

- Engagement: active participation of tourists is central to making them feel fully immersed in the context and to cultivating their special interests;

- Exploration: help tourists authentically experience the place by contributing to in-situ learning-by-doing practice.

The university's role in educational tourism is therefore closely linked with its regional role, and it is not limited to the education of foreign students: the experience of the place is, in fact, embedded into the educational journey. The university needs to work with the place to co-create meaningful learning experiences. At the same time, although being a secondary outcome of education, it actually contributes to create different touristic offers and packages, both directly (through co-creation with local players) and indirectly (by bringing travelling students in the region).

\subsubsection{International Students as Educational Tourists}

While living and studying abroad, international students also enjoy tourism and boost the local economy with their expenditure on transport, visits to cultural attractions, meals at restaurants and local food [37]. Even so, as Huang [2] noted, most academic tourism theories do not consider international students as tourists, unless their study period at the destination lasts less than one year, because they spend time in non-tourist settings. He argues, instead, that if we consider the full experience of international students, not only the academic one, we should not define them only as students. Travel is essential in their choice. Thus, international students can be seen as special interest or niche tourists: "The whole international student experience-touching, smelling, hearing, tasting and also seeing-in foreign countries, perfectly matches the 'tourism as an embodied practice' argument" (p. 1008).

Most of the studies on educational tourism have focused on of the reasons international students choose to attend study-abroad programs. The destination is significant, and its image and reputation $[2,9,13]$ are primary factors in the student's choice. Other factors include the safety and political stability of the destination, its cultural and touristic attractions, the events and leisure activities offered, the weather, the natural environment and the local lifestyle [2,8,51,52].

The image and reputation of the destination university is another important motivational factor: students consider the quality of its teaching programs and academic staff, its infrastructure and services, the availability of scholarships and the costs $[2,8,14]$. Other relevant factors in choosing the destination and the university are the geographical and cultural proximity, the presence of social ties, recommendations from trusted people, or even word of mouth $[8,11,13]$. Fortunately for researchers, students often record the reasons for their choices. Stone and Petrick [44] wrote a literature review identifying several aspects of educational tourism and analysing motivational factors. Table 3 summarises their list of motivational factors and provides a reference to the scholars who discussed them. 
Table 3. Motivational factors for educational tourism (adapted and further elaborated from Stone and Petrick [44]).

\begin{tabular}{ll}
\hline \multicolumn{1}{c}{ Motivation } & \multicolumn{1}{c}{ Authors } \\
\hline & Juvan and Lesjak [52] \\
A search for new experiences & Sanchez, Fornerino, and Zhang [53] \\
& Taylor and Rivera [54] \\
& Sanchez, Fornerino, and Zhang [53] \\
A good opportunity to travel & van Hoof [55] \\
\hline
\end{tabular}

Table 3. Cont.

\begin{tabular}{|c|c|}
\hline Motivation & Authors \\
\hline To live in or learn about another culture & van Hoof [55] \\
\hline The desire to be somewhere different & Juvan and Lesjak [52] \\
\hline Exposure to a different culture/language & Doyle et al. [56] \\
\hline $\begin{array}{l}\text { Desire for personal growth and increased } \\
\text { independence }\end{array}$ & Glover [51]; Castillo Arredondo et al. [57] \\
\hline $\begin{array}{l}\text { Wish to immerse themselves in another culture and } \\
\text { language }\end{array}$ & $\begin{array}{l}\text { Chew and Croy [58]; Lee [13]; Abubakar et al. } \\
\text { [11]; Liang et al. [41] }\end{array}$ \\
\hline Gaining academic knowledge & Lam et al. [10] \\
\hline Understanding of the host country & Sie et al. [59] \\
\hline Living a complete social experience & Huang [2]; Sie at al. [59] \\
\hline $\begin{array}{l}\text { Future opportunities given by study abroad, also } \\
\text { about professional and career development }\end{array}$ & $\begin{array}{l}\text { Glover [51]; Nyaupane et al. [9]; Lam et al. [10]; } \\
\text { Abubakar et al. [11]; Tashlai and Ivanov [12] }\end{array}$ \\
\hline
\end{tabular}

\subsubsection{Benefits of Educational Tourism}

Study abroad can have immediate benefits, such as learning or improving skills in a language, gaining knowledge in academic disciplines, and growing socially and emotionally, as students become more independent, mature and self-confident, and improve their interpersonal skills. Students who study abroad can also acquire intercultural competence [60]; that is, they gain specific knowledge about the host culture, come to an understanding of cultural differences, overcome prior stereotypes, and develop a broader awareness of the world around them. The study abroad experience allows them to practice critical thinking and reflect on the learning experience. It can influence their affections and attitudes. Living in a foreign context, they may be prompted to re-evaluate their own cultural identity and personal values, and may change their worldview, belief systems, and vocation. Study abroad can also contribute to modifying the students' attitudes and feelings about other cultures and can help them become more tolerant of ambiguity or learn to adapt to it. They may grow in their observation skills, develop new styles or strategies for learning information, improve their academic achievement, and learn to function more effectively in multicultural groups [60]. To sum up, the most common benefits are intrapersonal and interpersonal development, also in terms of interculturality and cultural self-awareness, academic and career benefits, growth in knowledge and skills, and social engagement and active citizenship [12,41,44,59-62].

The benefits of study abroad programs are not limited to the students, as these visitors can have a positive impact on the host country as well. For example, if they engage in activities related to the sustainable development of the host countries, there can be an exchange of benefits. A few scholars have explored the social interactions between tourists and hosts in educational tourism [63-65]. Moscardo [66] described knowledge-sharing and capacity-building to help communities interact positively with tourists. If several stakeholders jointly organise educational tourism activities, this may lead to "the realisation of a step-change in the strategic implementation of a curriculum aimed at enhancing students' professional and practice-based learning by offering an innovative programme which facilitated access to resources, knowledge exchange, capacity-building, cross-cultural and philanthropic collaborations and, 
as part of the university corporate commitment to sustainability, a contribution towards sustainable development practices in the wider community" [67]. Stable international programs benefit the university and the destination by increasing the internationalisation of the university, creating fertile terrain for the formation of new partnerships, fostering conditions for multiculturality and integration, and attracting new students, tourists and investors in the long term. Moreover, the students' presence at the local level would lead to cultural exchange between residents and international students, and would influence the attitude of local communities towards students in socio-cultural terms [68]. All these factors may contribute to the sustainable development of a local system.

\subsection{Impact of Educational Tourism on the Destination}

The benefits of educational tourism to host countries have economic and social relevance. As mentioned above, the presence of study-abroad programs provides more opportunities for local entrepreneurs, economic benefits for small businesses and employment opportunities for local people. The level of interaction with international students may influence the perception of residents. A study about Malaysia [68] showed that the presence of international students at an educational tourism hub could improve the quality of life for residents through the provision of increased opportunities for local entrepreneurs, economic benefits to small businesses and employment opportunities for local people.

The economic impact of international study programs on destination countries has been explored in a number of studies. As mentioned in the Introduction, one study explored the impact of American study abroad programs in Italy [26] (see Introduction), and another assessed the economic impact of international students in the U.K. Along similar lines, Obrien and Jamnia [69] argued that international students can contribute to the local economy through:

- on-campus spending directly related to their studies;

- off-campus spending on housing, food, books, transportation, clothing and entertainment;

- contribution to the local tourism industry through domestic travel and other tourist activities;

- non-educational tourism spending by students, visiting friends and relatives (VFR) and the return visits of alumni.

As a consequence, international educational tourism can lead to an increase in the sales of goods and services, and related tax revenue, as well as job creation [69].

Rezapouraghdam et al. [70] described the benefits brought by international students in Northern Cyprus, but noted some drawbacks as well. As benefits, students spend on food, school supplies, and transportation, and give more business to travel agencies and, if they bring their cars, to local insurance agencies. Construction businesses profit as 'dead' areas are exploited for the construction of new accommodations. Banks benefit from loans taken out by firms that can expand because of the influx of business from international students, as well as from financial services to students, such as money transfers, checking and savings accounts, and currency exchanges. Finally, student expenditures also bring in tax revenue. Negative aspects, according to the authors, include an increase in costs to residents, such as:

- higher prices for accommodations and shop rentals in the university area compared to the suburbs;

- fewer part-time and full-time jobs for local people, as international students take them at lower pay;

- the decline of the local economy in the summer, when students are away;

- excessive competition in the market for services dedicated to students.

International students can also have a direct economic impact on tourism in the host country. In Australia, Weaver [71] found that all the international students of the sample group visited the local tourist attractions or other regions, mostly on their own initiative. Moreover, as mentioned above, visiting friends and relatives can also have a substantial impact on the local economy [71], as they usually add tours of the destination and nearby regions. According to Asiedu [72], these visits are one of the foremost motivators in tourism. 
Particularly in non-urban areas, tourism may contribute to demographic stability and socioeconomic sustainability [73]. This type of tourism has the potential to generate local prosperity through decent jobs and better incomes [74]. In this matter, as highlighted in the Introduction, the presence of international students at a destination creates new entrepreneurial and employment opportunities related to the students' expenses at the local level. In some cases, new services are built to respond to students' needs for housing, cultural activities, and leisure and entertainment opportunities. The social impact of international students is, therefore, significant. From an environmental and social perspective, also, tourism in rural areas promotes environmental awareness and contributes to a positive attitude both in locals and tourists in terms of the respect, protection and conservation of the local cultural and natural heritage [73,74]. Cultural exchange between international students and locals brings its own social benefits. International students may actively engage in projects drawing together university and local stakeholders and bring positive contributions to the local context. Furthermore, this exchange between students and locals can help local communities become more aware of their own cultural identity, which, in rural areas, is a fundamental component in the promotion of territorial development and governance [75].

\section{Conclusions}

This work explored the role of HEIs in fostering local development through educational tourism. Statistical data show that the number of students studying abroad throughout the world is increasing. Research has provided evidence about the significant impact of international education tourism, including students' potential involvement in place-based activities, increased tourism business, and economic and social benefits to the host country $[20,21,23,24]$, which relate to the sustainability of this form of tourism for the destination. In turn, these educational tourists also benefit from their experiences personally and professionally [27].

This paper presents academic contributions that define educational tourism. Moreover, it explores the role of universities in enhancing educational tourism and in promoting local development; to do so, the authors, in this study, considered international students as educational tourists, and provided a description of the outcomes of educational tourism for students and destinations. In this context, it is possible to conclude that HEIs-as regional educational hubs-can enhance the potential of educational tourism destinations [26,76]. To this end, policymakers should work with HEIs to optimise and expand their educational exchange programs and make them more attractive to students. International educational tourism programs could work in collaboration with university information centres in other countries to promote their offerings. In addition, HEIs and actors at the destinations could collaborate on marketing strategies to communicate a positive image of both the institution and the destination, through outlets such as airline on-board magazines and the materials of other transportation companies, and with destination management organisations [69]. Finally, the alumni of study abroad programs can serve as 'brand ambassadors' for the university and destination, making them known and recommending them when they return home $[26,69,76]$.

Further research is needed, however, to give evidence and formulate models of intervention for the more strategic and operational deployment of educational tourism as a means for supporting the regional dimension of universities. We know from previous literature that the presence of international students impacts local communities, partly through an increase in local development. However, it is not clear whether this impact is the natural consequence that tourism of any kind would cause, or whether it derives from a deliberate university strategy as part of the design and management of its educational offer.

Author Contributions: Conceptualization, S.T., G.P. and A.C.; methodology, A.C.; investigation, S.T. and G.P.; writing - original draft preparation, A.C. (Section 2), G.P. (Sections 1 and 3.3.1), S.T. (all other paragraphs and sections); writing-review and editing, S.T. and G.P. All authors have read and agreed to the published version of the manuscript.

Funding: This research received no external funding. 
Acknowledgments: We would like to thank Sheila Beatty for editing the English usage in the manuscript.

Conflicts of Interest: The authors declare no conflict of interest.

\section{References}

1. International Mobility of the Highly Skilled-OECD. Available online: http://www.oecd.org/migration/mig/ internationalmobilityofthehighlyskilled.htm (accessed on 12 June 2020).

2. Huang, R. Mapping Educational Tourists': Experience in the UK: Understanding International Students. Third World Q. 2008, 29, 1003-1020. [CrossRef]

3. Richards, G. Creativity and Tourism. The State of the Art. Ann. Tour. Res. 2011, 38, 1225-1253. [CrossRef]

4. McGladdery, C.A.; Lubbe, B.A. Rethinking Educational Tourism: Proposing a New Model and Future Directions. Tour. Rev. 2017, 72, 319-329. [CrossRef]

5. Pine, B.J.; Gilmore, J.H. The Experience Economy: Past, Present and Future; Sundbo, J., Sørensen, F., Eds.; Edward Elgar Publishing: Cheltenham, UK, 2013; pp. 21-44.

6. Wenger, E. Communities of Practice and Social Learning Systems. Organization 2000, 7, 225-246. [CrossRef]

7. Sie, L.; Patterson, I.; Pegg, S. Towards an Understanding of Older Adult Educational Tourism through the Development of a Three-Phase Integrated Framework. Curr. Issues Tour. 2016, 19, 100-136. [CrossRef]

8. Michael, I.; Armstrong, A.; King, B. The Travel Behaviour of International Students: The Relationship between Studying Abroad and Their Choice of Tourist Destinations. J. Vacat. Mark. 2004, 10, 57-66. [CrossRef]

9. Nyaupane, G.P.; Paris, C.M.; Teye, V. Study Abroad Motivations, Destination Selection and Pre-Trip Attitude Formation. Int. J. Tour. Res. 2011, 13, 205-217. [CrossRef]

10. Lam, J.M.S.; Ariffin, A.A.M.; Ahmad, H.J.A. Edutourism: Exploring the Push-Pull Factors in Selecting a University. Int. J. Bus. Soc. 2011, 12, 63-78.

11. Abubakar, A.M.; Shneikat, B.H.T.; Oday, A. Motivational Factors for Educational Tourism: A Case Study in Northern Cyprus. Tour. Manag. Perspect. 2014, 11, 58-62. [CrossRef]

12. Tashlai, I. Educational Tourism-The Case of Eastern European Students: Driving Forces, Consequences, and Effects on the Tourism Industry. Master's Thesis, Cardiff Metropolitan University, Cardiff, UK, 2014.

13. Lee, C.-F. An Investigation of Factors Determining the Study Abroad Destination Choice. J. Stud. Int. Educ. 2014, 18, 362-381. [CrossRef]

14. Rahman, M.S.; Osman-Gani, A.M.; Raman, M. Destination Selection for Education Tourism: Service Quality, Destination Image and Perceived Spirituality Embedded Model. J. Islam. Mark. 2017, 8, 373-392. [CrossRef]

15. Carayannis, E.G.; Campbell, D.F.J. Triple Helix, Quadruple Helix and Quintuple Helix and How Do Knowledge, Innovation and the Environment Relate to Each Other? A Proposed Framework for a Trans-Disciplinary Analysis of Sustainable Development and Social Ecology. Int. J. Soc. Ecol. Sustain. Dev. 2010, 1, 41-69. [CrossRef]

16. Trencher, G.; Yarime, M.; McCormick, K.B.; Doll, C.N.H.; Kraines, S.B. Beyond the Third Mission: Exploring the Emerging University Function of Co-Creation for Sustainability. Sci. Public Policy 2014, 41, 151-179. [CrossRef]

17. Goddard, J.; Kempton, L. The Civic University Universities in Leadership and Management of Place; Centre for Urban and Regional Development Studies, Newcastle University: Newcastle, UK, 2016.

18. Goddard, J.B.; Hazelkorn, E.; Kempton, L.; Vallance, P. The Civic University: The Policy and Leadership Challenges; Edward Elgar: Cheltenham, UK, 2016.

19. Hénard, F.; Diamond, L.; Roseveare, D. Approaches to Internationalisation and Their Implications for Strategic Management and Institutional Practice; OECD: Paris, France, 2012.

20. Mosler, E.; Dag Tjaden, J. GLOBAL MIGRATION INDICATORS 2018. Insights from the Global Migration Data Portal: Www.Migrationdataportal.Org; Global Migration Data Analysis Centre (GMDAC) International Organization for Migration: Berlin, Germany, 2018.

21. Organization for Economic Cooperation and Development (OECD). Education at a Glance 2018; Education at a Glance; OECD: Paris, France, 2018. Available online: https://doi.org/10.1787/eag-2018-en (accessed on 12 June 2020).

22. Factsheets Erasmus+. Available online: https://ec.europa.eu/programmes/erasmus-plus/about/factsheets_en (accessed on 12 June 2020). 
23. Learning Mobility Statistics—Statistics Explained. Available online: https:/ec.europa.eu/eurostat/statisticsexplained/index.php/Learning_mobility_statistics (accessed on 12 June 2020).

24. Universities UK. The Economic Impact of International Students; Oxford Economics: London, UK, 2017.

25. NAFSA International Student Economic Value Tool|NAFSA. Available online: https://www.nafsa.org/ policy-and-advocacy/policy-resources/nafsa-international-student-economic-value-tool-v2 (accessed on 12 June 2020).

26. Borgioli, A.; Manuelli, A. Educating in Paradise: The Value of NorthAamerican Study Abroad Programs in Italy-Characteristics, Impact and Prospects Research and Study; ISTITUTO REGIONALE PER LA PROGRAMMAZIONE ECONOMICA DELLA TOSCANA: Firenze, Italy, 2013.

27. Alumni Survey Results|IES Abroad|Study Abroad. Available online: https://www.iesabroad.org/studyabroad/benefits/alumni-survey-results (accessed on 12 June 2020).

28. European Commission. Erasmus Impact Study; European Union: Luxembourg, 2014; Available online: https://doi.org/10.2766/75468 (accessed on 12 June 2020).

29. Weiler, B.; Hall, C.M. Special Interest Tourism; Belhaven Press: London, UK, 1992.

30. Holdnak, A.; Holland, S.M. Edu-Tourism: Vacationing to Learn. Park. Recreat. 1996, 31, 72-75.

31. Bodger, D. Leisure, Learning, and Travel. J. Phys. Educ. Recreat. Danc. 1998, 69, 28-31. [CrossRef]

32. Ritchie, B.W.; Carr, N.; Cooper, C.P. Managing Educational Tourism; Channel View Publications: Bristol, UK, 2003.

33. Gibson, H. The Educational Tourist. J. Phys. Educ. Recreat. Danc. 1998, 69, 32-34. [CrossRef]

34. Pitman, T.; Broomhall, S.; Majocha, E. Teaching Ethics beyond the Academy: Educational Tourism, Lifelong Learning and Phronesis. Stud. Educ. Adults 2011, 43, 4-17. [CrossRef]

35. Falk, J.H.; Ballantyne, R.; Packer, J.; Benckendorff, P. Travel and Learning: A Neglected Tourism Research Area. Ann. Tour. Res. 2012, 39, 908-927. [CrossRef]

36. Pitman, T.; Broomhall, S.; Mcewan, J.; Majocha, E. Adult Learning in Educational Tourism. Aust. J. Adult Learn. 2010, 50, 219-238.

37. Nugroho, H.P.; Soeprihanto, J. GadjahMada University as a Potential Destination for Edutourism. In Heritage, Culture and Society: Research Agenda and Best Practices in the Hospitality and Tourism Industry, Proceedings of the 3rd International Hospitality and Tourism Conference, ISOT 2016, Yokohama, Japan, 10-12 October 2016; CRC Press/Balkema: Boca Raton, MA, USA, 2016; pp. 293-298.

38. Burkart, A.J.; Medlik, S. Tourism: Past, Present and Future; William Heinemann Ltd.: London, UK, 1974.

39. Crouch, D. Places around Us: Embodied Lay Geographies in Leisure and Tourism. Leis. Stud. 2000, 19, 63-76. [CrossRef]

40. Boydell, T. Experiential Learning; Direct Design: Dorset, UK, 1976.

41. Liang, K.; Caton, K.; Hill, D.J. Lessons from the Road: Travel, Lifewide Learning, and Higher Education. J. Teach. Travel Tour. 2015, 15, 225-241. [CrossRef]

42. Dewey, J. Experience and Education; Macmillan: New York, NY, USA, 1938.

43. Kolb, D.A. Experiential Learning: Experience as the Source of Learning and Development; Prentice-Hall: Upper Saddle River, NJ, USA, 1984.

44. Stone, M.J.; Petrick, J.F. The Educational Benefits of Travel Experiences. J. Travel Res. 2013, 52, $731-744$. [CrossRef]

45. Trencher, G.P.; Yarime, M.; Kharrazi, A. Co-Creating Sustainability: Cross-Sector University Collaborations for Driving Sustainable Urban Transformations. J. Clean. Prod. 2013, 50, 40-55. [CrossRef]

46. Atterton, J.; Thompson, N. University Engagement in Rural Development: A Case Study of the Northern Rural Network. J. Rural Community Dev. 2010, 5, 123-132.

47. Wardle, C.; Buckley, R.; Shakeela, A.; Castley, J.G. Ecotourism's Contributions to Conservation: Analysing Patterns in Published Studies. J. Ecotourism 2018, 1-31. [CrossRef]

48. Charles, D. The Rural University Campus and Support for Rural Innovation. Sci. Public Policy 2016, 43, 763-773. [CrossRef]

49. Rinaldi, C.; Cavicchi, A.; Spigarelli, F.; Lacchè, L.; Rubens, A. Universities and Smart Specialisation Strategy: From Third Mission to Sustainable Development Co-Creation. Int. J. Sustain. High. Educ. 2018, 19, 67-84. [CrossRef] 
50. Sharma, A. Educational Tourism: Strategy for Sustainable Tourism Development with Reference of Hadauti and Shekhawati Regions of Rajasthan, India. J. Bus. Econ. Inf. Technol. 2015, 2. Available online: https://www.researchgate.net/publication/306017352_Educational_Tourism_Strategy_for_Sustainable_ Tourism_Development_with_reference_of_Hadauti_and_Shekhawati_Regions_of_Rajasthan_India (accessed on 12 June 2020).

51. Glover, P. International Students: Linking Education and Travel. J. Travel Tour. Mark. 2011, 28, 180-195. [CrossRef]

52. Lesjak, M.; Juvan, E.; Ineson, E.M.; Yap, M.H.T.; Axelsson, E.P. Erasmus Student Motivation: Why and Where to Go? High. Educ. 2015, 70, 845-865. [CrossRef]

53. Sánchez, C.M.; Fornerino, M.; Zhang, M. Motivations and the Intent to Study Abroad among U.S., French, and Chinese Students. J. Teach. Int. Bus. 2006, 18, 27-52. [CrossRef]

54. Taylor, M.; Rivera, D. Understanding Student Interest and Barriers To Study Abroad: An Exploratory Study. Consort. J. Hosp. Tour. 2011, 15, 56-72.

55. Hoof, V.; Hensen, J.L.M. Thermal Comfort and Older Adults. Gerontechnology 2006, 4, 223-228. [CrossRef]

56. Doyle, S.; Gendall, P.; Meyer, L.H.; Hoek, J.; Tait, C.; McKenzie, L.; Loorparg, A. An Investigation of Factors Associated with Student Participation in Study Abroad. J. Stud. Int. Educ. 2010, 14, 471-490. [CrossRef]

57. Castillo Arredondo, M.I.; Rodríguez Zapatero, M.I.; Pérez Naranjo, L.M.; López-Guzmán, T. Motivations of Educational Tourists in Non-English-Speaking Countries: The Role of Languages. J. Travel Tour. Mark. 2018, 35, 437-448. [CrossRef]

58. Chew, A.; Croy, W.G. International Education Exchanges: Exploratory Case Study of Australian-Based Tertiary Students' Incentives and Barriers. J. Teach. Travel Tour. 2011, 11, 253-270. [CrossRef]

59. Sie, L.; Phelan, K.V.; Pegg, S. The Interrelationships between Self-Determined Motivations, Memorable Experiences and Overall Satisfaction: A Case of Older Australian Educational Tourists. J. Hosp. Tour. Technol. 2018, 9, 354-379. [CrossRef]

60. Bolen, M.C. A Guide to Outcomes Assessment in Education Abroad; Forum on Education Abroad: Carlisle, PA, USA, 2007.

61. Dweyer, M.M. More Is Better: The Impact of Study Abroad Program Duration. Front. Interdiscip. J. Study Abroad 2005, 10, 151-163. [CrossRef]

62. Paige, R.M.; Fry, G.W.; Stallman, E.M.; Josić, J.; Jon, J. Study Abroad for Global Engagement: The Long-term Impact of Mobility Experiences. Intercult. Educ. 2009, 20 (Suppl. 1), S29-S44. [CrossRef]

63. Cohen, E.H. Self-Assessing the Benefits of Educational Tours. J. Travel Res. 2016, 55, 353-361. [CrossRef]

64. Riggs, E.M. Field-Based Education and Indigenous Knowledge: Essential Components of Geoscience Education for Native American Communities. Sci. Educ. 2005, 89, 296-313. [CrossRef]

65. Wright, S.; Suchet-Pearson, S.; Lloyd, K. An Interwoven Learning Exchange: Transforming Research-Teaching Relationships in the Top End, Northern Australia. Geogr. Res. 2007, 45, 150-157. [CrossRef]

66. Moscardo, G. Building Community Capacity for Tourism Development; Cabi Intl: Wallingford, UK, 2008.

67. Novelli, M.; Burns, P. Peer-to-Peer Capacity-Building in Tourism: Values and Experiences of Field-Based Education. Dev. South. Afr. 2010, 27,741-756. [CrossRef]

68. Abu Samah, A.; Ahmadian, M.; Gill, S.S.; Babolian Hendijani, R. Factors Affecting Educational Tourism Development among Local Communities in the Klang Valley, Malaysia. Life Sci. J. 2012, 9, 1097-8135.

69. Obrien, P.; Mojdeh, J. International Educational Tourism and Regional Development in Taiwan: A Discussion Paper. Pan-Pacific Manag. Rev. 2013, 16, 163-189.

70. Behravesh, E.; Rezapouraghdam, H.; AriWinifred, E.; Doh, L. Cost-Benefit Analysis of Educational Tourism in North Cyprus: A Qualitative Study of the Socio-Economic Impacts. e-Rev. Tour. Res. 2018, 15, 457-479.

71. Weaver, D.B. The Contribution of International Students to Tourism beyond the Core Educational Experience: Evidence from Australia. Tour. Rev. Int. 2008, 7, 95-105. [CrossRef]

72. Asiedu, A.B. Participants' Characteristics and Economic Benefits of Visiting Friends and Relatives (VFR) Tourism-An International Survey of the Literature with Implications for Ghana. Int. J. Tour. Res. 2008, 10, 609-621. [CrossRef]

73. Ibănescu, B.-C.; Stoleriu, O.; Munteanu, A.; Iațu, C. The Impact of Tourism on Sustainable Development of Rural Areas: Evidence from Romania. Sustainability 2018, 10, 3529. [CrossRef]

74. International Labour Office. Sustainable Tourism-A Catalyst for Inclusive Socio-Economic Development and Poverty Reduction in Rural Areas; International Labour Office: Geneva, Switzerland, 2019. 
75. Basile, G.; Cavallo, A. Rural Identity, Authenticity, and Sustainability in Italian Inner Areas. Sustainability 2020, 12, 1272. [CrossRef]

76. Matahir, H.; Tang, C.F. Educational Tourism and Its Implications on Economic Growth in Malaysia. Asia Pac. J. Tour. Res. 2017, 22, 1110-1123. [CrossRef]

(c) (

(C) 2020 by the authors. Licensee MDPI, Basel, Switzerland. This article is an open access article distributed under the terms and conditions of the Creative Commons Attribution (CC BY) license (http://creativecommons.org/licenses/by/4.0/). 